\title{
Verlange na die vleispotte van Pretoria en die Baai
}

\begin{tabular}{|c|c|}
\hline $\begin{array}{l}\text { Book Title: } \\
\text { Die slaghuis }\end{array}$ & \\
\hline Book Cover: & \\
\hline WEPENER & DIS \\
\hline $\begin{array}{l}\text { Author: } \\
\text { Cas Wepener }\end{array}$ & \\
\hline $\begin{array}{l}\text { ISBN: } \\
978-1-4853-1\end{array}$ & $065-5$ \\
\hline $\begin{array}{l}\text { Publisher: } \\
\text { Protea Boekh } \\
\text { Pretoria, } 201 \\
\text { *Book price a }\end{array}$ & $\begin{array}{l}\text { uis, } \\
\text { R } 200 * \\
\text { time of review }\end{array}$ \\
\hline $\begin{array}{l}\text { Review Title: } \\
\text { Verlange na } \\
\text { van Pretoria }\end{array}$ & $\begin{array}{l}\text { ie vleispotte } \\
\text { n die Baai }\end{array}$ \\
\hline $\begin{array}{l}\text { Reviewer: } \\
\text { Benito Trollip }\end{array}$ & \\
\hline $\begin{array}{l}\text { Affiliation: } \\
{ }^{1} \text { South Africa } \\
\text { Digital Langu } \\
\text { (SADiLaR), No } \\
\text { University, Po } \\
\text { South Africa }\end{array}$ & $\begin{array}{l}\text { Centre for } \\
\text { ge Resources } \\
\text { rth-West } \\
\text { tchefstroom, }\end{array}$ \\
\hline $\begin{array}{l}\text { Correspondin } \\
\text { Benito Trollip } \\
\text { benito.trollip }\end{array}$ & $\begin{array}{l}\text { g author: } \\
\text { @nwu.ac.za }\end{array}$ \\
\hline $\begin{array}{l}\text { How to cite } t \\
\text { Trollip, B., } 20 \\
\text { na die vleispo } \\
\text { en die Baai ', } \\
\text { a1676. https: } \\
\text { 10.4102/lit.v }\end{array}$ & $\begin{array}{l}\text { is book review: } \\
0, \text { 'Verlange } \\
\text { tte van Pretoria } \\
\text { iterator 41(1), } \\
\text { /doi.org/ } \\
111.1676\end{array}$ \\
\hline Read online & \\
\hline 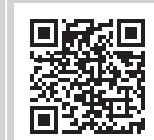 & $\begin{array}{l}\text { Scan this QR } \\
\text { code with your } \\
\text { smart phone or } \\
\text { mobile device } \\
\text { to read online. }\end{array}$ \\
\hline
\end{tabular}

Die slaghuis (2019) is Cas Wepener se jongste roman en speel af op 'n Oos-Kaapse dorp. Die verhaal sentreer hoofsaaklik om die lewens van die twee vrouens, twintig jaar uit mekaar uit: Kylie, 'n enkelma en munisipale beampte in 2017 en Marietta, die oudverpleegster en eggenote van oudbrigadier Karel Bergh in 1997. In 2017 is Kylie dertig jaar oud en is sy die enigste broodwinner wat vir haar seun, Joshua, moet sorg, asook vir haar pa wat agter in haar erf in 'n houthuis woon. Sy weet haar pa was op 'n manier by apartheidvergrype op die dorp betrokke, en dit is deels die rede waarom hulle nie met mekaar praat nie. Marietta is in 1997 'n getroude vrou wat saam met haar man, Karel, van Pretoria verhuis na dieselfde Oos-Kaapse dorpie (en ook dieselfde huis) waarin Kylie in 2017 woon. Marietta en Karel moet aan 'n nuwe lewe begin bou omdat Karel vir vervolging en sy verlede vlug. Daar is ook terugflitse na 1977 toe Karel en Kylie se pa op hierdie dorp ontmoet het, maar in ander omstandighede. Albei vrouens het te kampe met die besluite en aksies van verskillende mans in hulle lewens.

Die verhaal word deur frustrasie, isolasie, versugting en 'n algehele gebrek aan handeling gekenmerk. Kylie is vasgevang tussen verskillende mans en 'n werk wat haar frustreer. Sy bevind haar konstant tussen haar werk en haar huis en bekla haar lot as haar pa se dogter en haar seun se enkelma. Al waarna sy verlang, is Keagan, Joshua se pa, en die draairoomyse in die Baai wat sy, Joshua en pastoor John op 'n keer geniet het. Eweneens verlang Marietta in 1997 na haar en Karel se vorige lewe in Pretoria, waar sy ten minste die aandag geniet het van Malan, Karel se beste vriend en oudbevelvoerder. Al kontak wat Marietta met mense op die nuwe dorp het, is wanneer sy die slaghuis (in die tyd toe Kylie se pa nog die slagter was) en die mark, waar sy daagliks bestanddele vir nuwe disse aankoop, besoek. Karel is meestal in sy handjievol skape en die Minnaars se geselskap; hy meld slegs tuis aan wanneer Marietta met die kos klaar is. Die verhaal het afwisselende fokalisators, hoofsaaklik Kylie en Marietta. Daar is ook 'n gedeelte van die roman wat uit die perspektief van Joshua, Kylie se vierjarige seun, vertel word.

Die manier waarop Joshua ook as 'n fokalisator ingespan word, wek belangstelling. Benewens die feit dat hy Sarah, hulle huiswerker, meer as 'n moederfiguur ervaar as sy eie ma, is Joshua se grootste bekommernisse meestal die sepie wat hy en Sarah kyk en om Saterdae saam met sy ma te spandeer. Joshua verstaan ook basiese Xhosa, wat hom in staat stel om dele van die gesprekke tussen Moses en Sarah te volg. Myns insiens sou Joshua se vertelperspektief met meer vrug en met interessanter waarnemings aangewend kon word.

Wepener berei sy leser voor op die twee hoofelemente van sy roman, deur die aanhalings voor die aanvang van die eerste hoofstuk. Die fokus op kos en die bereiding van disse (veral deur Marietta), soos een aanhaling suggereer, herinner aan Schalk Schoombie se Rooi haring (2017). 'n Belangriker en duideliker verband bestaan met Grensgeval (2019), Marita van der Vyver se nuutste roman, in terme van die erkenning en hantering van 'n gedeelde verlede. In Grensgeval is Theresa die hoofkarakter - ook 'n vrou wat sin probeer maak van haar eksman, Theo, se aksies tydens 'n oorlog. Theresa word 'n aktiewe karakter wat besef dat Theo self 'n slagoffer van die oorlog was; sy het via Theo se posttraumatiese stres ook daaronder gely. Anders as Theresa, neem Kylie en Marietta nie 'n aktiewe rol in die ontlonting van die verlede in nie. Frustrasie kan op funksionele wyse in 'n roman ingespan word - en daar is inderdaad heelwat frustrasie in Die slaghuis - maar dan moet dit tot iets lei. Marietta se dramatiese ontboeseming aan Karel (beginnend op bl. 194) is 'n poging tot aktiewe handeling, maar dit motiveer Karel eerder tot verdere aksie en Marietta hou doodluiters aan met kos maak.

Uiteindelik is Die slaghuis 'n roman wat temas aanraak wat belangrik sal wees vir lesers wat glo dat ons nog lank nie klaar oor die verlede gepraat het nie. Hierdie temas word oortuigender en meer

Copyright: (C) 2020. The Authors. Licensee: AOSIS. This work is licensed under the Creative Commons Attribution License. 
genuanseerd in 'n roman soos Grensgeval hanteer. Desnieteenstaande die temas, sou die skrywer meer durf aan die dag kon lê om sy hoofkarakters aktief deel van die versoeningsproses te maak.

\section{Literatuurverwysings}

Schoombie, S., 2017, Rooi haring, Human \& Rousseau, Cape Town.

Van der Vyver, M., 2019, Grensgeval, Penguin Random House, Cape Town. 